\title{
A Case of Superior Semicircular Canal Dehiscence Syndrome with Coexisting Otosclerosis
}

\author{
Chan Joo Yang, Shin Ae Kim, Hwan Seo Lee, and Hong Ju Park \\ Department of Otolaryngology, Asan Medical Center, University of Ulsan College of Medicine, Seoul, Korea
}

\author{
이경화증이 동반된 상반고리관피열증후군 환자 1 예 \\ 양찬주 · 김신애 · 이환서 · 박홍주 \\ 울산대학교 의과대학 서울아산병원 이비인후과학교실
}

\author{
Received May 19, 2015 \\ Revised August 4, 2015 \\ Accepted August 6, 2015 \\ Address for correspondence \\ Hong Ju Park, MD, PhD \\ Department of Otolaryngology, \\ Asan Medical Center, \\ University of Ulsan \\ College of Medicine, \\ 88 Olympic-ro 43-gil, Songpa-gu, \\ Seoul 05505, Korea \\ Tel $+82-2-3010-3710$ \\ Fax +82-2-489-2773 \\ E-maildzness@amc.seoul.kr
}

Superior semicircular canal dehiscence (SSCD) syndrome and otosclerosis have overlapping clinical manifestations that can be difficult to distinguish. Audiovestibular symptoms are caused by noise or straining in SSCD, which is associated with the presence of an air-bone gap that overlaps with the characteristic of otosclerosis. We recently examined a 51-year-old woman presenting with unilateral pulsatile tinnitus and ipsilateral hearing loss in the left ear. Computerized tomography, audiometry and vestibular function test confirmed the diagnosis of ipsilateral SSCD syndrome with coexisting ipsilateral otosclerosis. The patient underwent surgical repair of dehiscence by middle fossa approach and stapes surgery for otosclerosis sequentially. She has not had pulsatile tinnitus postoperatively, and hearing improved with the closure of airbone gap at most frequencies. In conclusion, when SSCD syndrome and otosclerosis coexist and patient has representative symptoms of both ear pathologies, a sequential surgery can be an effective treatment option. Korean J Otorhinolaryngol-Head Neck Surg 2016;59(1):68-72

Key Words Otosclerosis · Semicircular canal ·

Superior semicircular canal dehiscence syndrome.

\section{서 론}

상반고리관피열증후군(superior semicircular canal dehiscence syndrome)은 1998년, Minor 등이 처음 명명한 증후군 으로, 상반고리관과 두개강 사이의 골피열로 인해 상반고리관 의 전정막미로가 중두개와 뇌경막에 노출되어, 압력(Hennebert 징후)이나 소리(Tullio 현상) 자극 시 현훈 또는 동요시 (oscillopsia) 등의 증상을 보인다. 이러한 특징적인 전정 증상 은 항상 동반되는 것은 아니며, 오히려 전음성 난청, 이충만감, 자가강청, 이명과 같은 비특이적인 청각 증상이 주요 증상으 로 보고되기도 한다. 또한 상반고리관피열증후군 환자들은 골 전도를 통한 소리에 과민함을 보여 눈 움직임이나 맥박 소 리, 발자국 소리 등 다양한 내재적인 체성 소음을 들을 수 있 으며,') 이러한 전정 및 청각 증상들은 중두개와 접근법을 통
한 상반고리관의 폐쇄를 통해 다양한 자극에 대해 증가되어 있는 전정 및 와우 반응을 억제시킴으로써 호전될 수 있다.1,4,5)

이경화증은 등골 족부, 와우 등에 골경화, 골해면화 혹은 섬유화 병변을 만드는 병변으로, 초기에는 전음성 청력 장애 를 일으키며 병변이 와우로 진행되면 혼합성 또는 감각신경성 난청을 일으킨다. ${ }^{6}$ 정상 고막 소견을 보이는 환자에서 20대 이 후부터 생긴 진행성의 전음성 난청이 있고, Gelle 검사에서 음 성 반응을 보이며 고해상도 측두골 전산화단층촬영에서 유양 돌기의 공기음영이 정상 소견을 보이는 경우 이 질환을 의심 할 수 있다. 확진을 위하여 시험적 고실개방술을 시행할 수 있 으며, 등골 고정이 확인된 경우 청력 회복을 위하여 등골절개 술이나 등골절제술 등 등골수술을 시행하게 된다.7)

전정 증상보다 청각 증상을 주로 나타내는 상반고리관피열 증후군은 흔히 이경화증으로 오인될 수 있는데, 그 이유는 두 
질환 모두 성인 시기에 나타나며 고막 소견은 정상이지만 청 력 검사 상에는 전음성 난청을 보일 수 있기 때문이다. 전음성 난청을 보이는 환자에서 이경화증 의심 하에 시험적 고실개방 술을 받고 심지어 등골절개술을 시행받았으나, 수술 장 소견 상 등골 고정이 관찰되지 않거나 수술 후에 청력의 호전이 없 어 추가 검사 후에 그 원인으로 상반고리관피열증후군을 진단 받은 사례가 보고된다. ${ }^{8,9)}$

상반고리관피열증후군과 이경화증은 전음성 난청이라는 중복되는 증상을 보이기 때문에, 여러 문헌에서 두 질환의 감 별 진단에 초점을 두고 설명을 함에도 불구하고 임상적으로 두 질환을 구분하기는 쉽지 않다. ${ }^{710)}$ 또한 외국 문헌에서 상반 고리관피열증후군과 이경화증이 동반된 전음성 난청 환자 2 예가 보고되었지만,11,12) 아직까지는 두 가지 질환이 동반된 환 자에서 치료 원칙이 명확히 확립되어 있지 않은 실정이며, 국 내에서는 이 두 가지 질환이 동반된 예가 보고된 바가 없었다. 저자들은 박동성 이명과 난청을 주소로 내원한 이경화증이 동반된 상반고리관피열증후군 환자 1 예를 경험하여 환자의 증 상과 증후, 다양한 검사결과와 향후 치료방침에 대해 문헌 고 찰과 함께 보고하고자 한다.

\section{증 례}

51세 여자 환자가 약 3년 전부터 서서히 진행하는 좌측 난 청과 이명을 주소로 내원하였다. 환자는 주로 좌측의 박동성 이명과 이충만감, 자가강청 및 간헐적 현훈을 호소하고 있었으 며, 이루, 청각과민, 소리에 의한 현훈의 증상은 없었다. 과거에 특별한 두부 외상의 병력 및 당뇨, 고혈압, 매독, 뇌수막염 등 의 병력은 없었다.

이학적 검사상 양측 고막에 특이 소견이 없었고, 호흡에 따
른 고막의 움직임도 관찰되지 않았다. 청진상 이명소리는 들 리지 않았다. 그러나, Weber 검사 $(512 \mathrm{~Hz})$ 상 좌측으로 편향되 는 소견과 함께 좌측의 Rinne 검사에서 음성의 소견이 보였 으며, 순음청력검사상 우측은 정상 소견이었으나 좌측의 전 주파수에서 혼합성 난청을 보였다(Fig. 1A). 또한, 좌측 외이 도에 양압을 주었을 때 좌측 안구의 내회선성 상향으로 향하 는 완서상 안구 운동을 확인할 수 있었다. 등골근 반사에서 좌측에서 무반응이 측정되었으며 온도안진 검사에서 반고리 관 마비나 방향 우위성은 관찰되지 않았다. 전정유발근전위검 사에서 우측은 역치가 $85 \mathrm{~dB}$ 로 측정되었으나 좌측에서는 반 응이 없었으며, 비디오두부충동검사 시행 시 모든 반고리관에 서 안구 운동은 정상이었다(Fig. 2A). 고해상도 측두골 전산 화단층촬영(0.6 mm thickness)에서 중이강 내 등골 주변 및 와우 주변에 특이 소견은 관찰할 수 없었다. 고해상도 측두골 전산화단층촬영 영상의 관상면 영상에서 상반고리관피열증 후군을 확인할 수 있었으며, 이를 상반고리관에 평행하게 영 상을 재구성한 면에서 $2.45 \mathrm{~mm}$ 정도의 상반고리관피열을 확인 할 수 있었다(Fig. 3A). 1년 전 타원에서 시행한 측두골 자기공 명 촬영과 본원에서 다시 시행한 측두골 자기공명촬영에서 뇌 실질의 종양이나 혈관의 비정상적인 소견은 관찰되지 않았다.

이상의 소견으로 상반고리관피열증후군과 이경화증이 동반 되었을 것으로 추정하였다. 환자에게 수술을 하지 않고 보청 기를 사용하는 보존적인 치료 방법을 포함하여 각 질환의 수 술적 치료 방법과 수술의 결과 및 합병증을 설명하였다. 환자 는 가장 불편한 증상인 박동성 이명에 대한 수술적 치료를 먼 저 받기를 원하여 중두개와 접근법을 통한 상반고리관의 폐쇄 술을 먼저 시행하기로 하였고, 이후 순차적으로 전음성 난청 에 대한 치료로 등골절개술을 계획하였다. 중두개와 접근법을 이용하여 두개저를 노출시키고 좌측 상반고리관을 덮고 있는

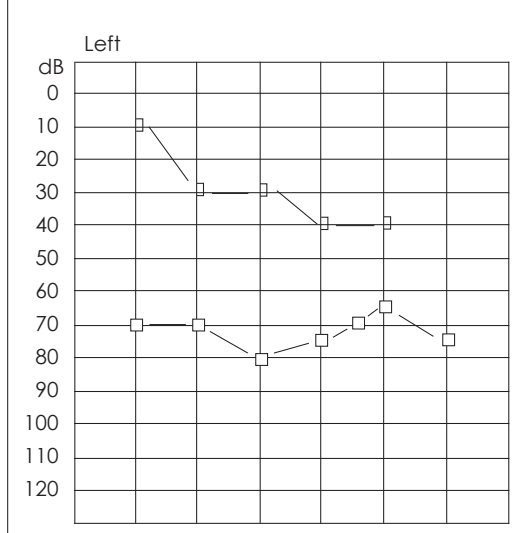

A
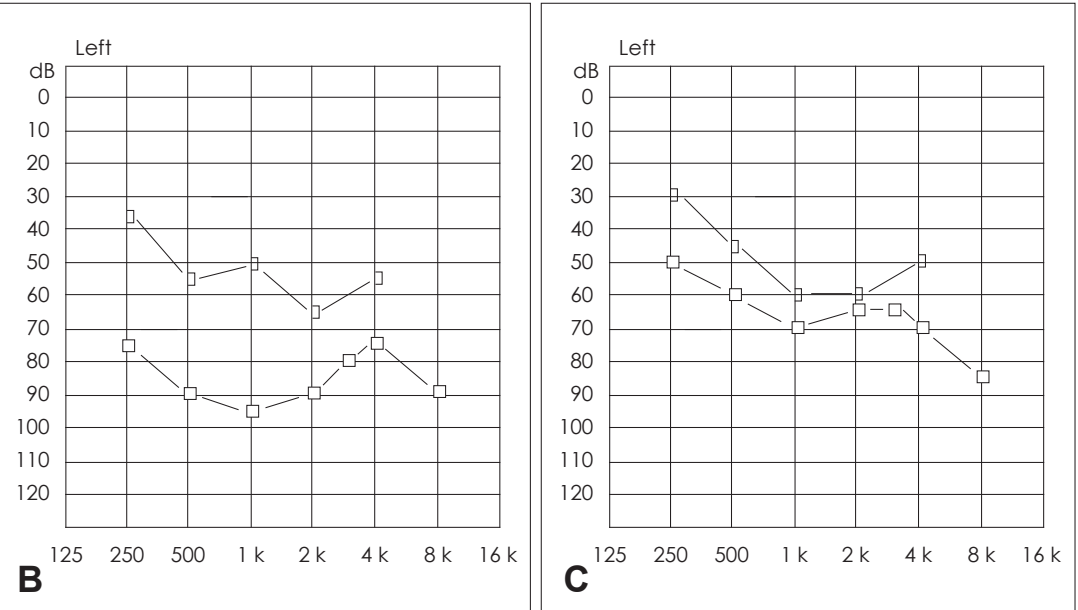

Fig. 1. Pre- and post-operative pure-tone thresholds in the ear with superior canal dehiscence and otosclerosis. (A) Initial preoperative audiometry, (B) Postoperative audiometry after repair of the superior canal dehiscence, (C) Postoperative audiometry after stapedotomy. 
뼈의 결손 부위를 확인하였다(Fig. 3B). 골 왁스로 골 결손 부 위를 폐쇄(plugging)하고 이주연골(tragal cartilage)로 덮고 섬 유소 응고제로 고정하고 수술을 종료하였다. 상반고리관 폐쇄 수술 이후 환자의 박동성 이명은 즉시 호전되었으나 현훈을 호소하였다. 수술 후 실시된 비디오두부충동검사에서 좌측의 모든 반고리관에서 이득이 감소되어 있었으며 교정 단속 운동 이 관찰되었다(Fig. 2B). 순음청력검사상 좌측의 전 주파수에 서 골도 청력역치의 악화를 보였다(Fig. 1B).

어지럼증은 전정재활운동을 통해 점차 감소되었으며, 상반
고리관 폐쇄 수술 4개월 후 국소 마취 하에 이내 접근법(endaural approach)을 사용하여 시험적 고실개방술을 시행하였 고 수술 소견상 등골 고정이 확인되었다. Skeeter drill(Medtronic-Xomed Inc., North Jacksonville, FL, USA)을 이용하여 등골절개술을 시행하고, Fisch type의 직경 $0.4 \mathrm{~mm}$ 의 pistonwire prosthesis(Fisch Fluoroplastic Piston; Medtronic-Xomed Inc.)를 이용하여 침골과 난원창과의 연쇄를 복원하였다. 수술 후 환자는 주관적인 청력 호전을 보였으며, 수술 후 한 달째 마지막으로 시행한 순음청력검사상 좌측의 기도-골도역치차

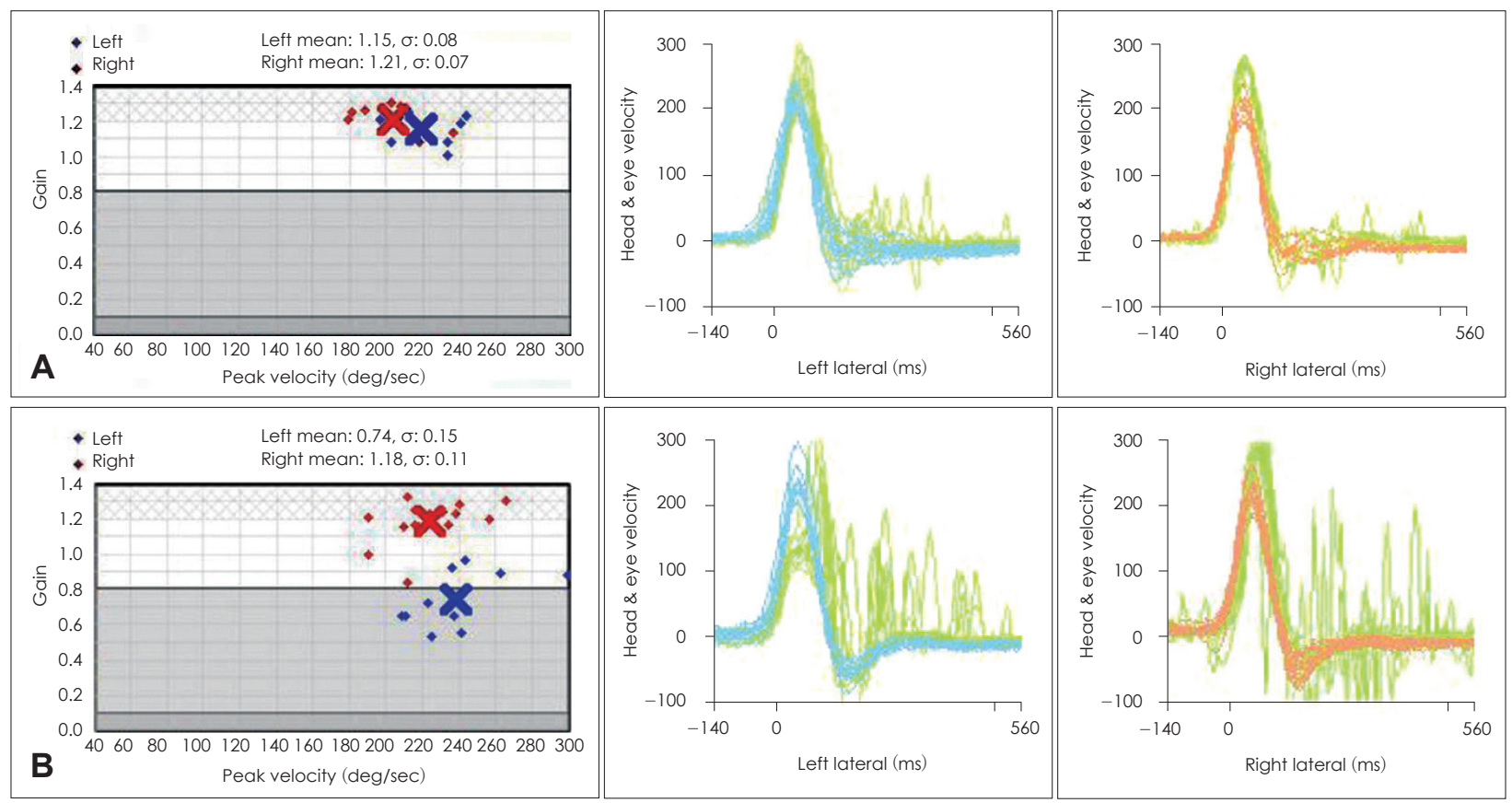

Fig. 2. Pre- and post-operative visual head impulse test. (A) Initial preoperative audiometry. (B) Postoperative audiometry after repair of the superior canal dehiscence and stapedotomy. Left mean: left mean gain, Right mean: right mean gain, $\sigma$ : standard deviation.
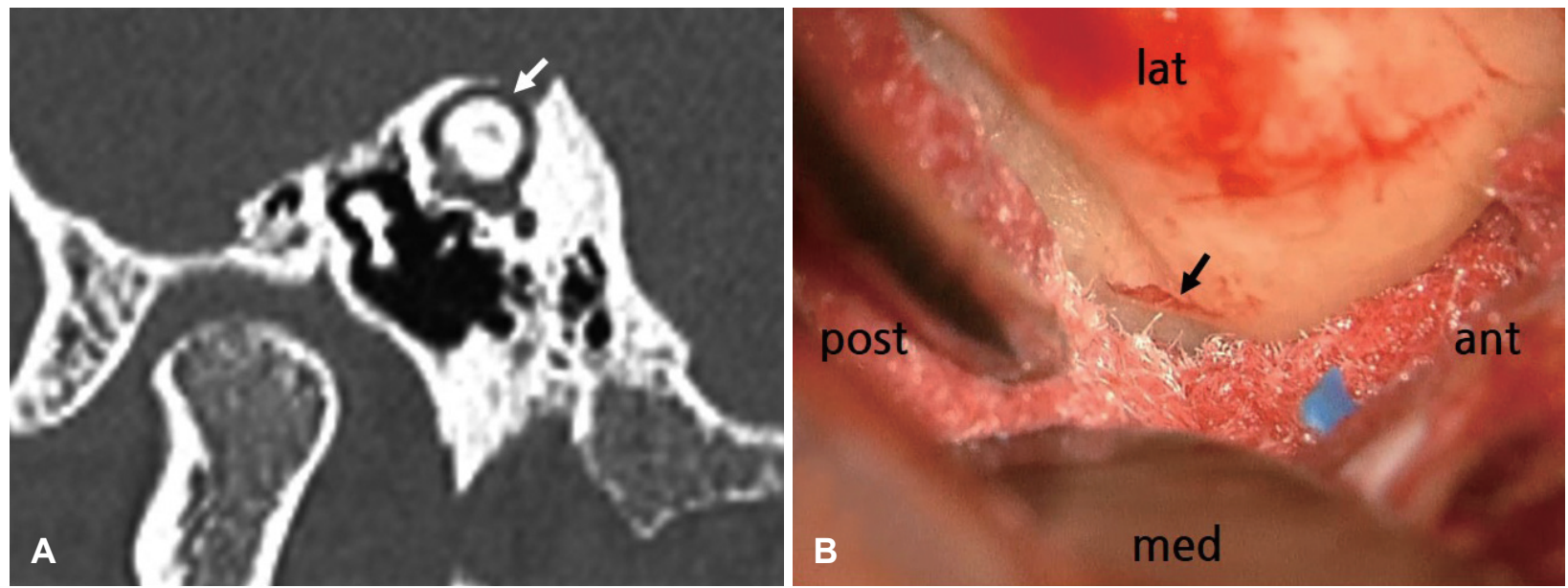

Fig. 3. Computed tomography and intraoperative finding in a patient with superior canal dehiscence. Preoperative high resolution computed tomography scans of the left temporal bone, demonstrating superior canal dehiscence syndrome. The reformatted image in the plane of the superior semicircular canal (SSC) clearly demonstrated a bony dehiscence of the superior canal. A dehiscence (white arrow) is seen overlying the left SSC (A). Intraoperative photograph of the patient's left temporal bone. A definite dehiscence of bone overlying the SSC is seen (black arrow) (B). ant: anterior, post: posterior, lat: lateral, med: medial. 
가 수술 전의 $35 \mathrm{~dB}$ 과 비교하여 수술 후 $10 \mathrm{~dB}$ 으로 줄어든 것 을 확인하였다(Fig. 1C). 수술 후 8개월까지 외래를 통해 경과 관찰하였으며 환자는 청력 및 박동성 이명의 호전을 보였지 만, 마지막 외래 내원 당시까지 간헐적인 현훈을 호소하여 전 정재활운동 및 약물 치료 중이다.

\section{고 찰}

상반고리관피열증후군은 난원창을 통해 내이로 전달된 에 너지가 '제3의 창(third window)'의 역할을 하는 상반고리관의 골피열 부위를 통해 비정상적으로 전달되어 여러 가지 청각 및 전정 증상이 유발되는 내이 질환의 하나이다. 상반고리관 피열증후군의 진단은 흔히 임상증상 및 증후, 청각 검사 소견, 소리 및 압력에 의해 유발되는 안진의 관찰, 그리고 전정유발 근전위 등으로 하게 되며, 여기에 더하여 고해상도 측두골 전 산화단층촬영이 중요한 역할을 하게 된다. ${ }^{2)}$ 상반고리관피열증 후군의 가장 특징적인 청각검사 소견은 전음성 난청으로 이는 기도역치가 상승하고 골도역치가 낮아져 기도-골도역치차가 발생한다. 그러나, 등골근 반사가 정상으로 나타나고 전정유발 근전위의 역치가 오히려 낮아지는 점은 전음성 난청이 중이 병변에 의한 현상이 아님을 반영한다. 일반적으로 전음성 난 청과 소리에 대한 특징적 안구 운동의 유발 유무 및 전정유발 근전위검사상의 비정상적으로 낮은 역치 등의 소견이 관찰되 어 상반고리관피열증후군이 의심되는 경우에 고해상도 측두 골 전산화단층촬영을 시행하는 것으로 보고된다. ${ }^{13)}$

상반고리관피열증후군 환자에서 이경화증이라는 오진을 하 고 부적절하게 등골 수술을 시행한 사례가 많이 보고가 되었 다. ${ }^{68)}$ 이는 두 가지 질환 모두 전음성 난청의 소견을 공통적으 로 보이기 때문으로, 상반고리관피열증후군 환자에서 전형적 인 전정 증상이 동반되지 않은 경우 이경화증과 감별이 어려 울 수 있다. 본 연구에서 경험한 환자는 상반고리관피열증후 군과 이경화증이 동반된 환자였는데 여러 가지 관점에서 상기 의 사례들과는 다른 증상 및 검사 소견 등이 발견되는 것을 알 수 있다.

본 증례 환자의 진단 과정을 살펴보면, 외래 초진에서 좌측 기도-골도역치차의 존재로 Weber 검사상 왼쪽으로 편향되는 소견을 보였으며, 순음청력검사상 전 주파수에서 전음성 난청 을 보였다. 또한 압박에 의해 특징적인 안구의 움직임과 현훈 이 관찰되어 상반고리관피열증후군을 의심할 수 있었다. 그러 나 병변 쪽 골도 청력 역치의 감소는 관찰되지 않았으며 상반 고리관피열증후군 환자에서 흔히 보이는 전음성 난청에 비해 서 기도-골도역치차의 폭이 큰 편이었다. 또한 전정유발근전위 검사에서 좌측에서 반응이 없고, 등골근 반사에서도 좌측에
이상소견을 보여 전음성 난청을 유발할 만한 다른 중이 내 질 환이 동반되었을 가능성을 의심하였다. 고해상도 측두골 전산 화단층촬영을 통해 쉽게 상반고리관피열증후군을 진단할 수 있었고, 중이 내에서는 특이 소견이 관찰되지 않았지만 다른 검사 결과를 참고하여 동반된 중이 질환으로 이경화증을 의 심하였다. 이경화증에서는 전도의 장애가 실제로 있는 상태이 므로 전정유발근전위검사와 등골근 반사에서 반응이 나오지 않게 된다. ${ }^{14)}$

상반고리관피열증후군과 이경화증이 동반된 경우에는 등 골 고정으로 인해 난원창의 역할이 사라지기 때문에 '제3의 창(third window)'으로 인해 발생할 수 있는 상반고리관피열 증후군의 전형적인 증상이 없을 수도 있다. 또한 두 가지 질환 모두 서서히 진행하는 특성이 있어 환자는 전정 기능 장애에 의한 증상은 어느 정도 적응이 되는 반면에 비교적 뚜렷이 나 타나는 청력 저하를 주로 호소를 하게 된다. 그렇기 때문에 두 가지 질환이 동반된 경우 상반고리관피열증후군을 간과하고 이경화증으로만 진단하는 경우가 발생할 수 있다. 따라서 다 양한 검사 결과를 면밀하게 살펴봐야 하며, 특히 고해상도 측 두골 전산화단층촬영은 상반고리관피열증후군의 진단에 큰 도움을 주기 때문에 의심이 되는 경우 고해상도 측두골 전산 화단층촬영을 진행하는 것이 좋다. 기보고된 외국의 사례에 서와는 달리 우리나라에서는 이경화증을 진단받고 시험적 고 실개방술을 진행하는 경우에 수술 전 고해상도 측두골 전산 화단층촬영을 시행하는 경우가 많기 때문에 상반고리관피열 증후군의 진단을 놓칠 확률은 비교적 낮다. 그러나 이와 반대 로, 고해상도 측두골 전산화단층촬영에만 의존해서 상반고리 관피열증후군의 진단을 할 경우 과다한 위양성을 보일 수 있 어 부정확한 진단에 따라 불필요한 수술적 처치가 시행되는 경우도 있어 주의하여야 한다. ${ }^{13)}$

본 증례의 환자의 경우 증상 및 여러 검사의 도움으로 진단 을 내리는 데에는 큰 어려움이 없었으나 치료 방향을 결정하 는 데에 어려움이 있었다. 기보고된 상반고리관피열증후군과 이경화증의 동반 사례가 드물었을 뿐만 아니라 보고된 사례 도 모두 본 증례와는 다른 점이 있었기 때문이다. 기보고된 2 가지 사례 중 1예는 이경화증 진단 하에 등골절개술 이후 전 음성 난청은 호전이 되었으나 현훈 등의 증상이 새로 발생하 여 전정유발근전위검사와 고해상도 측두골 전산화단층촬영 을 시행 한 후에 상반고리관피열증후군을 진단받은 경우이 며, ${ }^{11)}$ 다른 한 예는 진료 시 고해상도 측두골 전산화단층촬영 을 통해 이경화증과 상반고리관피열이 모두 발견되었으나, 환 자는 주로 청력 저하만을 호소하여 이에 대한 치료로 등골절 개술만을 시행한 경우이다. ${ }^{12)}$ 따라서 본 증례에서와 같이 상반 고리관피열증후군과 이경화증 두 가지 질환의 각각의 대표적 
인 증상이 동시에 있으면서, 치료 전 두 가지 질환의 진단이 모두 이뤄진 경우는 없었기 때문에 기존에 이와 같은 경우에 서 참고할 만한 치료 방침이 없었다. 상반고리관피열증후군과 이경화증에 대한 수술을 동시에 시행한다면 반고리관과 난원 창을 통해 내이를 양측에서 자극, 염증 등의 손상을 유발할 수 있으며, 본 증례의 환자처럼 수술 후 현훈이 발생하였을 경 우 그 원인으로 외림프누공 등의 발생 가능성에 대해서 알 수 가 없기 때문에 두 가지 수술을 순차적으로 하기로 하였다. 두 가지 질환이 동반된 환자에서 등골절개술을 먼저 진행하는 경우, 수술 전에는 등골 고정으로 인해 난원창을 통해 에너지 가 전달이 되지 않기 때문에 '제3의 창(third window)'으로 인 해 발생할 수 있는 상반고리관피열증후군의 전형적인 증상이 없으나 수술 후 난원창을 통해 내이로 에너지가 전달되며 상 반고리관피열증후군의 전형적인 증상이 새로 나타날 수 있 다. ${ }^{11)}$ 하지만 후자의 기존 보고에서 등골절개술 이후 현훈 등 의 증상이 새로 발생하지 않은 것으로 보아 상반고리관피열이 있다고 해서 등골절개술의 절대적 금기는 아니라는 것을 알 수 있다. ${ }^{12)}$ 본 증례의 환자는 치료 전에 이미 현훈 등의 전정 장애 증상이 전음성 난청과 동반된 상태였다. 따라서, 저자들 은 환자의 증상에 초점을 두고 환자와의 상담을 통해 치료 방 향을 결정하였다.

상반고리관피열증후군이나 이경화증 모두 수술적 치료를 시행할 경우 수술로 인해 합병증이 발생할 가능성이 있으며, 수술 후 감각신경성 난청과 현훈이 수술 부작용으로 발생할 수 있음이 보고된다. ${ }^{15,16)}$ 상반고리관피열폐쇄술을 시행할 경우 저음역에서 상반고리관의 피열의 교정에 의하여 골도 청력의 악화가 발생하며, 약 25\%의 환자에서 수술 후 고음역에서의 경도의 감각신경성 난청이 발생하는 것으로 보고된다. ${ }^{16)}$ 본 증 례에서도 최종적으로 기도 청력 역치는 술 전과 비교하여 호 전되었으나, 경도의 감각신경성 난청이 발생하였고, 수술 후 현훈을 호소하여 시행한 비디오두부충동검사에서 좌측 반고 리관의 기능 저하를 확인할 수 있었다. 따라서, 환자가 치료를 결정하는 과정에서 수술적 치료를 할 경우 발생할 수 있는 합 병증에 대한 충분한 설명이 필요할 것으로 생각된다.

상반고리관피열증후군과 이경화증 모두 흔한 질환은 아니 지만, 두 질환의 증상이 서로 중복되는 경우도 있어 감별 진단
을 정확히 해서 환자가 불편해하는 증상에 대한 환자의 이해 와 치료의 결정이 이루어지는 것이 중요할 것으로 생각된다.

\section{REFERENCES}

1) Minor LB, Solomon D, Zinreich JS, Zee DS. Sound- and/or pressureinduced vertigo due to bone dehiscence of the superior semicircular canal. Arch Otolaryngol Head Neck Surg 1998;124(3):249-58.

2) Zhou G, Gopen Q, Poe DS. Clinical and diagnostic characterization of canal dehiscence syndrome: a great otologic mimicker. Otol Neurotol 2007;28(7):920-6.

3) Watson SR, Halmagyi GM, Colebatch JG. Vestibular hypersensitivity to sound (Tullio phenomenon): structural and functional assessment. Neurology 2000;54(3):722-8.

4) Limb CJ, Carey JP, Srireddy S, Minor LB. Auditory function in patients with surgically treated superior semicircular canal dehiscence. Otol Neurotol 2006;27(7):969-80.

5) Brantberg K, Bergenius J, Tribukait A. Vestibular-evoked myogenic potentials in patients with dehiscence of the superior semicircular canal. Acta Otolaryngol 1999;119(6):633-40.

6) Schrauwen I, Van Camp G. The etiology of otosclerosis: a combination of genes and environment. Laryngoscope 2010;120(6):1195-202.

7) Lachance S, Bussières R, Côté M. Stapes surgery in profound hearing loss due to otosclerosis. Otol Neurotol 2012;33(5):721-3.

8) Minor LB, Carey JP, Cremer PD, Lustig LR, Streubel SO, Ruckenstein MJ. Dehiscence of bone overlying the superior canal as a cause of apparent conductive hearing loss. Otol Neurotol 2003;24(2):270-8.

9) Halmagyi GM, Aw ST, McGarvie LA, Todd MJ, Bradshaw A, Yavor RA, et al. Superior semicircular canal dehiscence simulating otosclerosis. J Laryngol Otol 2003;117(7):553-7.

10) Merchant SN, Rosowski JJ, McKenna MJ. Superior semicircular canal dehiscence mimicking otosclerotic hearing loss. Adv Otorhinolaryngol 2007;65:137-45.

11) Hope A, Fagan P. Latent superior canal dehiscence syndrome unmasked by stapedotomy for otosclerosis. J Laryngol Otol 2010;124 (4):428-30.

12) Pritchett CV, Spector ME, Kileny PR, Heidenreich KD, El-Kashlan HK. Surgical treatment of hearing loss when otosclerosis coexists with superior semicircular canal dehiscence syndrome. Otol Neurotol 2014; 35(7):1163-7.

13) Carey JP, Minor LB, Nager GT. Dehiscence or thinning of bone overlying the superior semicircular canal in a temporal bone survey. Arch Otolaryngol Head Neck Surg 2000;126(2):137-47.

14) Zhou G, Poe D, Gopen Q. Clinical use of vestibular evoked myogenic potentials in the evaluation of patients with air-bone gaps. Otol Neurotol 2012;33(8):1368-74

15) Wegner I, Kamalski DM, Tange RA, Vincent R, Stegeman I, van der Heijden GJ, et al. Laser versus conventional fenestration in stapedotomy for otosclerosis: a systematic review. Laryngoscope 2014;124(7):168793.

16) Ward BK, Agrawal Y, Nguyen E, Della Santina CC, Limb CJ, Francis $\mathrm{HW}$, et al. Hearing outcomes after surgical plugging of the superior semicircular canal by a middle cranial fossa approach. Otol Neurotol 2012;33(8):1386-91. 